E Q U I L I B R I U M

Volume 6 IsSue 1, 2011

IS S N $1689-765 \mathrm{X}$

Alena Novák Sedlácková
University of Zilina, Slovakia

\title{
IMPACT OF Crisis ON The CONTEMPORARY IsSues in Economic Regulation of Airports
}

JEL Classification codes: $L 51$

Keywords: economic regulation, airports, airport charges, EU directive

\begin{abstract}
This paper is about impact of crisis on the contemporary issues in economic regulation of airport charges and implementation of EU Directive in the Slovak Republic. The problems of creation and application of European legislation started just before crisis and the most important regulation formulas have been created during the crisis.
\end{abstract}

\section{Introduction}

Economic regulation is still a hot topic. Economic regulation is a process, which was due to restrictions monopoly of the market players in imperfect competition. There is an interaction of political and economic forces that have resulted in invention of necessary institutional set regulator of restrictive or controlling nature. But what really is an economic regulation? Stephen Littlechild, who was father of price cap regulation said: "Regulation is essentially a means of preventing the worst excesses of monopoly; it is not a substitute for competition. It is a means of holding the fort until the competition arrives" (Littlechild 1983).

Economic regulation was here before the crisis, during the crisis and remained after the crisis. It is one of the current problems in the economy. The paper deals with problems of economic regulation of airports and airport charges, because civil aviation was seriously hit by crisis. Intense discussions on the economic regulation of airports at the European level have begun before the crisis. Although the crisis did not stop the debate, it did change the initially strict European leaders approach to this issue. 


\section{Economic regulation of airport charges}

Economic and political union will ultimately depend on the will of European leaders and its citizens. There is the tension within EU policy-making between the tendency to regulate and the encouragement of national governments and authorities to deregulate. This is often a concern of business. The emphasis has now been shifted towards deregulation and privatization as the route to international competitiveness. And that is a step, which is very important for air transport market and civil aviation. The current aims of the transport policy are to establish a single market for all forms of transport, allowing free access to the market in each member state and environmental sustainability. Liberalization of every form of transport is also in progress. This has proved the most difficult aspects of transport policy. All these factors have substantial influence on the airport economics. It is a perfect moment to find the balance between the airport capacity and expenses on it. The fundamental cost items are staff costs, maintenance expenses, depreciation, amortization and impairment (operating expenses). There has to be balance and match between the expenses and revenues. The basic idea of business is the effort to make a profit. The fundamental revenue items are airport taxes, parking fee, security fee, handling revenue, landing fee, financial revenue and other commercial revenues.

The situation on the air transport market is difficult. In the past it was a regulated market, later deregulation process started in the world's air transport market and now we are thinking about regulation in the liberalized market. Economic regulation of natural monopoly demands shoots up in the air transport market. The question is whether the airport is the natural monopoly or not? Samuelson localized the position of air transport somewhere in the middle between the natural monopoly and perfect competition.

The specialists claim that the airport is geographically limited natural monopoly. This position is very important. The regulators secure compliance of rules of maximum level of aeronautical charges. The legal environment plays an important role for the airport competitiveness. In particular, regulations on the aeronautical charges that are different between countries will impact the airport competitiveness compared to other airports. Competition from other airports is at best limited if existent. Market power enables airports to raise their prices (airport charges), and to extract rents from the customers. Therefore the rationale for regulating airports has seldom been questioned. Regulation aims at controlling costs and prices, and the quality of services. 


\section{Economic regulation of airport charges and European Union policy}

The result of the EU is that the economic regulation is very important. After three long years they issued the fundamental Directive on airport charges. But that means only the necessity of regulation, not the process how to do it. This Directive shall be without prejudice to the right of each Member State to apply additional regulatory measures that are not incompatible with this Directive or other relevant provisions of Community law with regard to any airport managing body located in its territory. This may include economic oversight measures, such as the approval of charging systems and/or the level of charges, including incentive-based charging methods or price cap regulation. The methods how to implement this directive and how to regulate depend on the each Member state.

The Directive shall apply to any airport located in a territory subject to the Treaty and open to commercial traffic whose annual traffic is over five million passenger movements as well as to the airport with the highest passenger movement in each Member State which enjoys a privileged position as a point of entry to that Member State. It is necessary to apply the Directive to that airport in order to guarantee respect for certain basic principles in the relationship between the airport managing body and the airport users, in particular with regard to transparency of charges and non-discrimination among airport users. The ICAO Council has considered that an airport charge is a levy that is designed and applied specifically to recover the cost of providing facilities and services for civil aviation, while a tax is a levy that is designed to raise national or local government revenues which are generally not applied to civil aviation in their entirety or on a cost-specific basis. Airport charges should be non-discriminatory.

The Directive stipulates that a compulsory procedure for regular consultation between airport managing bodies and airport users should be put in place with the possibility for either party to have recourse to an independent supervisory authority whenever a decision on airport charges or the modification of the charging system is contested by airport users. In order to ensure impartial decisions and the proper and effective application of the Directive, an independent supervisory authority should be established in every Member State. Member States shall guarantee the independence of the independent supervisory authority by ensuring that it is legally distinct from and functionally independent of any airport managing body and air carrier. Further, it is vital for airport users to obtain from the airport managing body, on a regular basis, information on how and on what basis airport charges are calculated. Such transparency would provide air carriers with an insight into the costs incurred by an airport and the productivity of an airport's investments. To allow an airport managing body to properly assess the requirements with regard to future investments, the airport users should be required to share all their operational forecasts, development projects and 
specific demands and suggestions with the airport managing body on a timely basis. Member States shall take the necessary measures to allow the airport managing body to vary the quality and scope of particular airport services, terminals or parts of terminals, with the aim of providing tailored services or a dedicated terminal or part of a terminal. The level of airport charges may be differentiated according to the quality and scope of such services and their costs or any other objective and transparent justification. Member States shall bring into force the laws, regulations and administrative provisions necessary to comply with this Directive by 15 March 2011 (Directive 2009/12/EC of European Parliament and Council of 11 March 2009 on airport charges, „Official Journal of the European Union", L70/11, 14.3.2009).

\section{Economic regulation of airport charges and the Slovak Republic Policy}

In the Slovak Republic, the economic regulation of airports was paid less attention to than this interesting and currently very topical and important issue deserves, but the situation is changing. As it has been mentioned above, the European Parliament and Council adopted on $11^{\text {th }}$ March 2009, after very long technical discussions and commenting approval process, Directive 2009/12/EC of the European Parliament and of the Council on airport charges, which tells about the need for economic regulation of airports in all EU Member States, thus also in the Slovak Republic. This Directive is the first in history whose decisions and principles issued by ICAO give strength to the "hard law". Implementation of Directive 2009/12/EC on airport charges also depends on the strict legal interpretation, which states will be respected. Press release of the European Parliament says: "This legislation has to prevent abuse of the position of individual airports that are in the dominant market position." Parliament stresses that any differences in airport charges must be based on objective and clear criteria. Although the idea is very well and clearly identified, for the Slovak Republic and our biggest Airport Bratislava, it means many problems. To strat with, it is important to define the system of airport charges and the most important international airports in Slovak rebublic.

Out of a total of 8 international SK airports (Bratislava, Košice, Poprad-Tatry, Žilina, Sliač, Piešt’any, Nitra and Prievidza), only two, Bratislava and Košice, could be relevant for economic regulation of airport.

Košice airport is a small regional airport, but it has a great local position. This airport can be defined as a geographic monopoly, i.e. a natural monopoly; however, it is too small for regulation as the Directive applies to the airports that are above a minimum size ( 5 mil. pax), because management and the funding of small airports do not call for the application of the Community framework. 
Regarding Bratislava Airport, the Directive requires regulation of this airport as the biggest airport in Slovakia. However, experts on economic regulation believe that it is unnecessary, because this airport is not a local monopoly and is located close to Vienna Airport (only $60 \mathrm{~km}$ by highway). So what can we do? We have to respect principles of EU and the Directive and regulate airport charges there, but it can be the end. Bratislava airport aspires to compete with Vienna Airport, but currently does not have a sufficiently large passenger flow. The situation in the air transport market during the current economic crisis is complicated and some airlines have stopped operating from and to Bratislava airport. At this moment, the approach of the Ministry of Transport, Construction and Regional Development of the Slovak Republic is very important. This Ministry is responsible for the airport charges policy in the Slovak Republic and the implementation of the European legislation to national legal system. The economic regulation of the Slovak airports and airport charges is dependent on this approach.

\section{Allocation of airport charges in the Slovak Republic}

The airport charges of the airports in the Slovak Republic are published in Aeronautical Information Publication (AIP SR). In the Slovak Republic airport charges are divided into traffic within Slovak Republic and international traffic. This separation between domestic traffic and international traffic is in contradiction with the European law - Article 72 and 81 (1)d of EC Treaty, however European Court of Justice in Case C-92/01 has declared the specific situation in which such a separation is permissible, i.e. the costs of domestic flights must be legitimately lower than the costs of international flights.

Table 1. Rates per each tonne (even initiated) of the maximum take-off mass (MTOM) of the aircraft-traffic within the Slovak Republic (domestic traffic) in 2010

\begin{tabular}{|l|c|}
\hline \multicolumn{2}{|c|}{ Traffic within the Slovak Republic } \\
\hline Airports & Euros per tonne \\
\hline Košice & 10,963 \\
\hline Bratislava & 5,145 \\
\hline Nitra & 0,332 \\
\hline Piešt’any & 4,647 \\
\hline Pievidza & 0,332 \\
\hline Poprad-Tatry & 4,647 \\
\hline Sliač & 4,647 \\
\hline Žilina & 4,647 \\
\hline Trenčín & 1,327 \\
\hline
\end{tabular}

Source: AIP SR 2010 - Aeronautical Information Publication SR. 
Figure 1. Rates per each tonne (even initiated) of the maximum take-off mass (MTOM) of the aircraft- traffic within the Slovak Republic (domestic traffic)

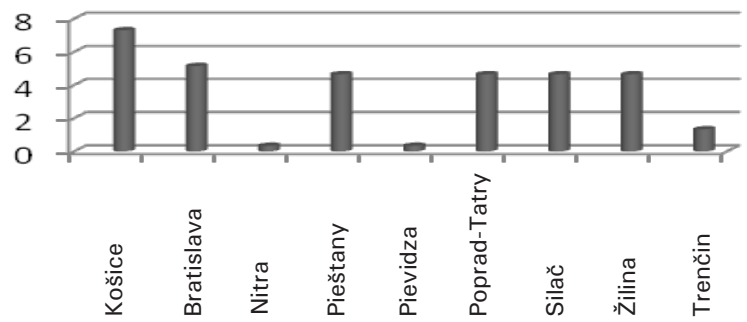

Source: own work.

Table 2. Rates per each tonne (even initiated) of the maximum take-off mass (MTOM) of the aircraft- International traffic

\begin{tabular}{|l|c|}
\hline \multicolumn{2}{|c|}{ International traffic } \\
\hline Airports & Euros per tonne \\
\hline Košice & 14,107 \\
\hline Bratislava & $13,111^{*}$ \\
\hline Piešt’any & 12,447 \\
\hline Poprad-Tatry & 12,447 \\
\hline Sliač & 12,447 \\
\hline Žilina & 12,447 \\
\hline
\end{tabular}

*On the Bratislava Airport are three categories of maximal take-off mass (MTOM): first $150 \mathrm{t}$, included aircraft landing charges are 13,111 euros per tonne each next 151 to $250 \mathrm{t}$ - aircraft landing charges are 9, 294 euros per tonne each next $251 \mathrm{t}$ - aircraft landing charges are 6,638 euros per tonne.

AIP SR 2010 - Aeronautical Information Publication SR.

Source: own work.

Figure 2. Rates per each tonne (even initiated) of the maximum take-off mass (MTOM) of the aircraft- International traffic

Source: own work.

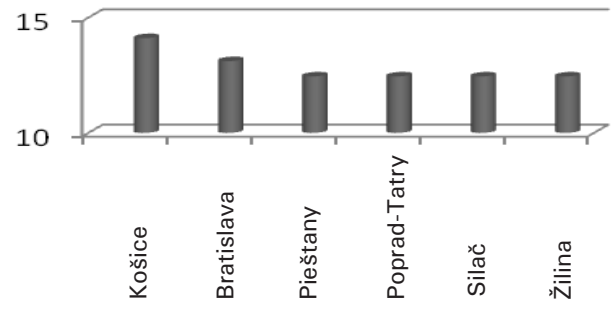

But airport charges are not only the landing charges but parking charges and airport taxes too. For the next part of the paper I have chosen only those airports, 
whose parking charges and airport taxes are relevant to this study and for economic regulation of Slovak airports, so I have chosen three biggest airports.

Table 3. Parking charges at Slovak airports

\begin{tabular}{|l|c|}
\hline \multicolumn{2}{|c|}{ Parking charges at the Slovak airports } \\
\hline Airports & Euros per MTOM \\
\hline Košice & 1,327 \\
\hline Bratislava & $0,298^{*}$ \\
\hline Poprad-Tatry & 0,298 \\
\hline
\end{tabular}

Source: AIP SR 2010 - Aeronautical Information Publication SR.

Figure 3. Parking charges at Slovak airports

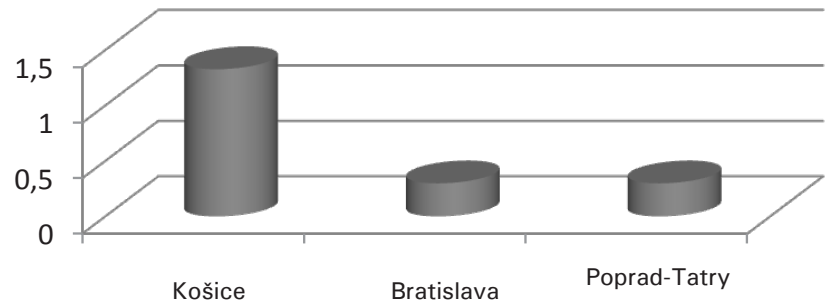

Source: own work.

The level of airport taxes is described in table 4.

The most expensive is Košice airport as for the parking charges too.

Table 4. Airport taxes at the Slovak airports

\begin{tabular}{|l|c|c|}
\hline \multicolumn{3}{|c|}{ Airport taxes at the Slovak airports (Euros per tonnes) } \\
\hline Airports & Domestic traffic & International traffic \\
\hline Košice & 10,455 & 16,265 \\
\hline Bratislava & 6,306 & 16,265 \\
\hline Poprad-Tatry & 4,315 & 14,339 \\
\hline
\end{tabular}

Source: AIP SR 2010 - Aeronautical Information Publication SR.

Figure 4. Airport taxes at the Slovak airports

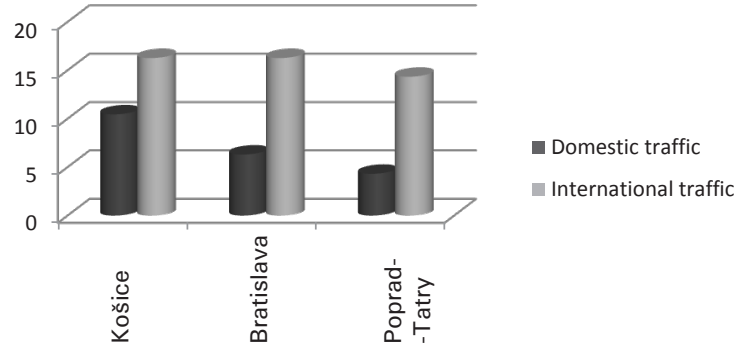

Source: AIP SR 2010 - Aeronautical Information Publication SR. 
Following this analysis I can identify some important parameters for economic regulation of airports. The tables show that economic regulation can be beneficial, because there are visible differences in the amount airport charges between the airports. I can say that Košice airport has the highest average airport charges. This is the result of its specific position in the market. Bratislava airport already has lower charges, but after application of Directive 209/12/ $\mathrm{EC}$ it has to be a regulated airport and my question is why? Why do we have to regulate the airport, which is highly competitive and we does not really need regulation?

Passengers are important for the implementation of economic regulation. EU wants to regulate the airport whose annual traffic is over five million passenger movements as well as the airport with the highest passenger movement in each Member State which enjoys a privileged position as a point of entry to that Member State. Košice has only around 0.6 million passenger movements, which is not the highest passenger movements level.

The next relevant indicator is the capacity of the regulated airport. Airports which can not increase their capacity have to be regulated since they have a specific market position and the regulator must eliminate their monopolistic position and the associated disproportionate profits. But it can only be done at the moment when all their slots are filled.

\section{Approaches to the economic regulation of airports in Europe and the Slovak Republic}

There are four main models through which airport charges can be regulated:

- rate of return regulation,

- price cap regulation,

- default price cap regulation,

- reserve regulation.

The rate of return regulation is also called cost-based or profit control regulation. This model is traditional for monopolies regulation. The aim is to prevent regulated entities from setting prices that are not related to costs. Thus, a certain ROR is stated and prices can be increased when there is an increased in costs. The disadvantage of this model is that it provides no incentives to reduce the cost. But the advantage is that it ensures the prices are related to costs. This is the indirect way of controlling prices, because prices above the competitive prices will result in an above-normal ROR of the sector (Tomová 2008).

The price cap regulation is an alternative regulatory model overcoming the shortcomings of the ROR regulation. It is considered to be more convenient as it 
provides the regulated firm with incentives to reduce costs. Simultaneously, this model controls price increases. It works by establishing following formulas:

$$
\text { price } c a p=\text { CPI }-\mathrm{X} \text { or price } \mathrm{cap}=\mathrm{RPI}-\mathrm{X} \text {. }
$$

CPI is the consumer price index and RPI is the retail price index. $\mathrm{X}$ is the efficiency gain target. If airports are regulated through price cap, the question is which facilities and services are to be considered. This type of regulation is simpler to be administered as company can change the level and structure of prices as long as it conforms to the price cap.

The default price cap system is based on a price cap that is available to all users. However, individual users are allowed to set up alternative contracts with the airport operator outside the price cap conditions if both parties agree. This mechanism can overcome the problem of quality of service, which is another field of major concern within any regulatory framework. Independent arrangements could therefore be established relating to levels of service quality. Any users wishing for a different level of service can negotiate this with the airport operator and these contracts can have different duration for different users.

The reserve regulation or the light handed approach means that the regulator is being involved in the price-setting process if the airport market power is abused or if the company or customers cannot reach agreement. This is more a threat of regulation rather than actual regulation (it was in New Zealand in 1998) (Tomová 2008).

There are two approaches within the regulatory regime with regards to scope of regulated activities:

- single till approach

- dual till approach.

Single till is used when all airports activities are included in the regulatory pricing regime. This regime was traditionally accepted by ICAO (International Civil Aviation Organization) in its charging recommendations. The reason is that without aeronautical activities there will be no market for commercial activities. But the airport industry itself represented through ACI (Airports Council International Administration) argues that single till is less incentive to develop commercial operations to their full potential and prefers dual till, which means that just the aeronautical side of the airports operation is under the regulatory pricing regime.

The situation in Slovakia and at the Slovak airports demonstrates some differences from those in other Member states. Airports are in a special and problematic position. After research of theoretical models commonly used in Europe, Latin America and Australia, a matrix or portfolio of various possibilities of al- 
ternative approaches to the application of economic regulation of the Slovak airports has been compiled and is evaluated on figure 5 .

Figure 5. Portfolio of various possibilities of alternative approaches to the application of economic regulation at Slovak airports

\begin{tabular}{|l|c|c|c|c|}
\hline \multirow{2}{*}{$\begin{array}{c}\text { Mechanism of Economic regulation of } \\
\text { airports }\end{array}$} & \multicolumn{3}{|c|}{ Approaches of ERoA } \\
\cline { 2 - 5 } $\begin{array}{c}\text { Hard } \\
\text { regulation }\end{array}$ & RoR & Single till & Dual till & Hybrid \\
\hline & Price cap & $\checkmark$ & & \\
\hline & Hybrid RoR a Price cap & & $\checkmark$ & \\
\hline & Default regulation & & & \\
\hline Soft regulation & Light handed & \multicolumn{3}{|c|}{$\checkmark$} \\
\hline
\end{tabular}

Source: Bratislava Airport after Application of Created Hard Regulation Formula of Economic Regulation of Airport Charges.

Simulation of situation at Bratislava Airport after the introduction of the hard regulation formula - price cap single till - is one of the opportunities how to analyse the situation and choose the best method of regulation. On the other hand, the research illustrates the possibilities of economic regulation, which of the regulation mechanism is the best.

Price cap single till mechanism was considered the most appropriate for Bratislava Airport. The regulation formula is based on the research of the authors. Simulation is set for the five years period from 2010 till 2014. Data is from Bratislava Airport.

The fundamental parameters of regulation formula are planned revenue, real revenue, planned passengers, real passengers, quality of service, CPI, average interest, trigger and the investments towards the new Terminal 2 at Bratislava Airport.

The maximum permitted revenue per passenger for the regulatory period $2010\left(\mathrm{P}_{2010}\right)$ :

$$
\mathrm{P}_{2010}=\left[\mathrm{P}_{2009}+\mathrm{T}_{2010}\right] * \mathrm{QS}_{2010}
$$

Where:

$\mathrm{T} 2_{2010}=\mathrm{X}^{*}$ (number of days, when Terminal $\mathrm{T} 2$ is opened in the year 2010)/365,

$\mathrm{X}$ is set on the investments to the new Terminal 2 
$\mathrm{QS}_{2010}=$ represents a Quality of Service adjustment that takes a value between 0 and 1 depending on Quality of Services, which are provided by Bratislava Airport .

$$
\mathrm{QS}_{2010}=1-\sum_{\mathrm{x}=1}^{\mathrm{n}} \mathrm{QS}_{\mathrm{x}}
$$

this coefficient $\mathrm{QS}_{2010}$ has more monitor parameters of quality $\mathrm{n}$

The rules establish for $\mathrm{QS}_{2010}$ :

- number of days in 2010 when passengers in a terminal that is open have to queue for more than thirty minutes to pass through passenger security, subject to this sum never exceeding (QS1),

- number of days in 2010 when access to the outbound element of the baggage handling system is denied to an airline or airlines for more than thirty consecutive minutes due to a single event system failure (QS2),

- number of quarters in 2010 when the incoming element of the baggage handling system is available for less than $99 \%$ of operational hours (QS3),

- number of quarters that Bratislava airport breaks the rule of ACI 'ease of way-finding through airport'(QS4),

- number of quarters that Bratislava airport breaks the rule of ACI 'flight information screens' (QS5),

- number of quarters that Bratislava airport breaks the rule of ACI 'cleanliness of airport terminal'(QS6),

- number of quarters that Bratislava airport breaks the rule of ACI 'cleanliness of washrooms' (QS7),

- number of quarters that Bratislava airport breaks the rule of ACI 'comfort of waiting/gate (QS8),

- number of quarters that Bratislava airport breaks the rule of ACI 'courtesy/ helpfulness of airport staff (excluding check-in \& security)' (QS9),

- number of quarters that Bratislava airport breaks the rule of ACI 'courtesy/ helpfulness of security staff'(QS10),

- number of quarters that Bratislava airport breaks the rule of ACI 'all passengers' overall satisfaction with the airport' (QS11),

- number of quarters that Bratislava airport breaks the rule of ACI 'communications/ telecommunications/e-facilities' (QS12).

The maximum permitted revenue per passenger for the regulatory period $2011\left(\mathrm{P}_{2011}\right)$ :

$\mathrm{P}_{2011}=\left[\left(\mathrm{P}_{2010}+\mathrm{T} 2_{2011}+\right.\right.$ Trigger $\left.\left._{2011}\right) *\left(1+\mathrm{CPI}_{2010}\right)+\mathrm{k}_{2009}+\mathrm{w}_{2009}\right] * \mathrm{QS}_{2011}$ 
$\mathrm{T} 2_{2011}=X^{*}($ number of days, hen Terminal T2 is opened in the year 2011)/365

- Trigger2011 $=\sum$ sum of special coefficients

- sum of special coefficients, which depend on the special situations, conditions and changes in the legislation,

Where:

- this data depends on the expenses of passenger and investments to the runways (the runway trigger),

- a week in 2010 when demand for aircraft stands was greater than xy (the apron development trigger),

- legislation requires an upgrade of the Bratislava airport baggage security equipment prior to the end of 2011,

$\boldsymbol{C P I}_{2010}$ is the percentage change (whether of a positive or negative value) in the consumer price index between those published in October 2009 and October 2010 by National Bank of Slovakia (http://forecasts.org/cpi.htm ),

$\boldsymbol{k}_{2009}$ is a correction per passenger to be made in the regulatory year 2011

on account in the regulatory year 2009. It is derived from the following formula:

$$
k_{2009}=\left(Y_{2009 f}-Y_{2009}^{*}\right) *\left(\frac{\operatorname{Pax}_{2009}}{\operatorname{Pax}_{2009 f}}\right) *\left(1+\frac{I_{2009}}{100}\right) *\left(1+\frac{I_{2010}}{100}\right)
$$

$Y_{2009 f}$ is the forecast average revenue per passenger collected from airport charges levied at Bratislava airport in 2009,

$Y^{*}{ }_{2009}$ is the actual average revenue per passenger collected from airport charges levied at Bratislava airport in 2009,

$\operatorname{Pax}_{2009 f}$ is the forecast number of passengers using Bratislava airport during 2009 ,

$\operatorname{Pax}_{2009}$ is the actual number of passengers using Bratislava airport during 2009 ,

$I_{2009}$ is the average year interest rate between 1 October 2008 and 1 October 2009 (www.nbs.sk 15.5.2010),

$I_{2010}$ is the average year interest rate between 1 October 2009 and 1 October 2010, which is set in the forecast for the next period (http://forecasts.org/5yrT. htm 18.5.2010),

$W_{2009}$ is a correction per passenger to be made in the regulatory year 2011 on account of any difference for the year 2009 - actual costs and expenses and budgeted costs and expenses that are recoverable through airport charges levied at Bratislava airport. It is derived from the following formula:

$$
\mathrm{w}_{2009}=\left[\mathrm{WA}_{2009}-\left(\mathrm{WF}_{2009} *\left(1+\mathrm{CPI}_{2009}\right)\right)\right] *\left(\frac{1}{\operatorname{Pax}_{2009 \mathrm{f}}}\right) *\left(1+\frac{\mathrm{I}_{2009}}{100}\right) *\left(1+\frac{\mathrm{I}_{2010}}{100}\right)
$$


$W A_{2009}$ - real costs, which are paid from airport charges

$W F_{2009}$ - forecast costs, which are paid from airport charges

This correction is very important, since the correction renders the formula more realistic, however, at this moment, its value is set at 0 because Bratislava Airport could not estimate this value and coefficient. The maximum permitted revenue per passenger for the regulatory period 2012, 2013 and 2014 can be evaluated and set on the same basis and formulas with actual data and values.

Table 5. Simulation parameter values at Bratislava airport after application of hard regulation formula - price cap single till

\begin{tabular}{|c|c|c|c|c|c|c|c|}
\hline \multirow{2}{*}{ Parameter } & \multicolumn{7}{|c|}{ YEAR } \\
\hline & 2008 & 2009 & 2010 & 2011 & 2012 & 2013 & 2014 \\
\hline $\begin{array}{l}\text { Forecast } \\
\text { revenue per } \\
\operatorname{pax}[\mathrm{Yn}]\end{array}$ & $14,88 €$ & $12,94 €$ & $13,38 €$ & $13,89 €$ & $14,28 €$ & $15,04 €$ & $15,32 €$ \\
\hline \multirow{2}{*}{$\begin{array}{l}\text { Correction } \\
\text { coefficient [kn] }\end{array}$} & \multirow{2}{*}{-} & $-4,65 €$ & $-4,49 €$ & $-2,45 €$ & $-0,91 €$ & $-0,30 €$ & \\
\hline & & $-11,01 €$ & $-13,48 €$ & $4,35 €$ & $24,03 €$ & $13,99 €$ & \\
\hline $\begin{array}{c}\text { Quality } \\
\text { coefficient- } \\
\text { Quality of } \\
\text { Services [QSn] }\end{array}$ & - & - & 0,965 & 0,945 & 0,935 & 0,935 & 0,935 \\
\hline $\begin{array}{c}\text { Costs per pax } \\
\text { in T2 [Tn] }\end{array}$ & - & - & $1,80 €$ & $2,13 €$ & $2,41 €$ & $2,29 €$ & $0,96 €$ \\
\hline \multirow{2}{*}{$\begin{array}{l}\text { Revenues per } \\
\text { pax }[\mathrm{Pn}]\end{array}$} & \multirow{2}{*}{$16,02 €$} & \multirow{2}{*}{$19,94 €$} & $20,98 €$ & $17,99 €$ & $15,73 €$ & $15,49 €$ & $15,53 €$ \\
\hline & & & $20,98 €$ & $11,44 €$ & $0,34 €$ & $6,53 €$ & $29,47 €$ \\
\hline $\begin{array}{c}\text { Revenues per } \\
\operatorname{pax}[\mathrm{Pn}][\mathrm{kn}=0 \\
\text { a wn=0] }\end{array}$ & $16,02 €$ & $19,94 €$ & $20,98 €$ & $21,84 €$ & $22,67 €$ & $23,34 €$ & $22,72 €$ \\
\hline $\begin{array}{l}\text { Total airport } \\
\text { revenue /pax } \\
\text { forecast }\end{array}$ & $14,88 €$ & $12,94 €$ & $13,38 €$ & $13,89 €$ & $14,28 €$ & $15,04 €$ & $15,32 €$ \\
\hline $\begin{array}{c}\text { Total airport } \\
\text { revenue /real } \\
\text { pax }\end{array}$ & $16,02 €$ & $19,94 €$ & $23,28 €$ & $24,18 €$ & $24,14 €$ & $24,23 €$ & $23,55 €$ \\
\hline
\end{tabular}

Source: own work.

\section{Conclusion}

I created a hard regulation formula, which could be introduced at the Bratislava Airport after the 11th of March, 2011. The formula based on the fundamental 
theoretical knowledge and the special practical analyses and research in the Slovak Republic, especially Bratislava Airport.

The regulation formula has many positive and negative aspects. The main negative aspect is the problem with the quality of data that can be provided by Bratislava Airport. I do not have enough data for a correction of coefficient which can be used to adjust the formula and make the maximum permitted revenue per passenger for the regulatory period more realistic.

This research indicates that the model of "hard regulation" in the Slovak Republic - revenue price cap single till - is not suitable for this kind of airports, because it is overly complicated and the Slovak Republic does not have enough experiences with economic regulation of airports to carry it out. Bratislava Airport wants to increase the passenger flow and the number of airlines with base in Bratislava, so the goal is to have airport charges at the lowest possible level.

After analysis and selection of relevant parameters we hope to demonstrate in further research that the best way for Bratislava Airport is the light handed regulation (monitoring of prices).

\section{Literature}

AIP SR 2010 - Aeronautical Information Publication SR.

Bugaj M., Novák A. (2003), Optimalizácia zberu údajov z leteckej prevádzky v prostredí všeobecného letectva. [in:] Znižovanie nehodovosti v civilnom letectve-2003: medzinárodný seminar, Žilina.

Data from Bratislava airport in April 2010, long-term financial plan 2008-2025, „Annual Reports Bratislava Airport 2004-2008".

Directive 2009/12/EC of European Parliament and Council of 11 March 2009 on airport charges, Official Journal of the European Union, L70/11, 14.3.2009.

Forsyth P. (2002), Privatisation and regulation of Australian and New Zealand airports, „Journal of Air Transport Management”, Vol. 8.

Starkie D. (2002), Airport Regulation and competition. Elsevier Science.

Tomová A. (2008), Air Transport Economics Airports, EDIS, Žilina. http://forecasts.org/cpi. htm date 17.5.2010, http://portal.statistics.sk/showdoc.do?docid=15694 17.5.2010.

www.nbs.sk 15.5.2010, http://forecasts.org/5yrT.htm 18.5.2010.

Topolčány R., Kandera B. (2005), Letecké právne normy. Definície a skratky. 1. vyd. - Žilina: Žilinská univerzita, AH 11,20, VH 11,61: obr., tab. 